\title{
Malignancy risk for fine-needle aspiration of thyroid nodules according to the bethesda system for reporting thyroid cytopathology, at king abdul-aziz, national guard hospital
}

\begin{abstract}
Introduction: The Bethesda System was introduced to help us in risk of malignancy in reporting thyroid cytopathology. The Bethesda system is high predictive value of thyroid fine needle aspirates. FNA of the thyroid gland is an accurate method in our approach to manage our patient.
\end{abstract}

Aim: The aim of this study was to determine the rates of malignancy of thyroid nodules in each standard cytologic diagnostic category of Bethesda system in our hospital.

Materials and methods: A retrospective cross-sectional study in which all cases of thyroid nodules, presented to the OPC between September 2009 and August 2015 at King Abdulaziz NGHA. All preoperative cytologic examination by FNA and concurrent postoperative histopathologic examination were included. All FNA diagnoses were reclassified using the thyroid FNA Bethesda reporting system, including non-diagnostic, benign, atypical follicular lesion of undetermined significance, follicular/hurthle cell neoplasm, suspicious for malignancy and malignant categories, the rate of malignancy based on final histopathologic evaluation was analyzed for each of these cytologic groups.

Results: We reviewed 237 thyroid FNA samples and recorded interpretations according to the proposed standardized 6 categories and pursued follow-up cytology and histology. Of the 237 FNAs, $4.2 \%$ were nondiagnostic, 39.2\% were benign, $15.6 \%$ were AFLUS, $8.9 \%$ were SFN, $16.9 \%$ were SM, and $15.2 \%$ were malignant

The rates of malignancy in histology were as follows: nondiagnostic, $0.0 \%$ benign, $4.3 \%$; AFLUS, 18.9\%; SFN $34 \%$ : SM 95.0\% and malignant, $94.4 \%$

Conclusion: The Bethesda system is a standardized system of reporting thyroid cytopathology, improving communication between cytopathologists and clinicians leading to ideal management approaches

Keywords: bethesda system, cyto-histological correlation, fine needle aspiration cytology, rate of malignancy
Volume 7 Issue 3 - 2017

\section{Omimah Abdullah,' Fahad Al Saab² \\ 'Specialist otorhinolaryngology, Saudi Arabia \\ ${ }^{2}$ Consultant pediatric Otolaryngology, Saudi Arabia}

Correspondence: Omimah Abdullah specialist otorhinolaryngology, Saudi Arabia,

Email Dr.omimah.abdullah@gmail.com

Received: May 13,2017 | Published: June 01, 2017
Abbreviations: FNA, fine-needle aspiration; NCI, national cancer institute; TBSRTC, the bethesda system for reporting thyroid cytopathology;

\section{Introduction}

Thyroid nodules occur commonly and can be detected by ultrasound in $60 \%$ of the general population. ${ }^{1-3}$ The Surveillance Epidemiology and End Results Registry (SEER Registry) shows increasing prevalence of differentiated thyroid cancer in the world ${ }^{4,5}$ mostly due to the increased detection of small papillary carcinomas. ${ }^{6}$ For initial evaluation of patients with thyroid nodules, fine-needle aspiration (FNA) of the nodules is safe, simple, accurate, cost effective, and widely accepted. ${ }^{7}$ FNA of the thyroid allows $70-80 \%$ of lesions to be classified as benign or malignant, with a $92 \%$ negative predictive value for benign nodules and a $100 \%$ positive predictive value for malignancy. ${ }^{8}$ FNA reduces the rate of unnecessary thyroid surgery for patients with benign lesions and appropriately triages patients with thyroid malignancy for appropriate management. ${ }^{9}$

The literature is deficient with regard to the precise frequency of thyroid nodules and the associated rate of malignancy in Saudi Arabia.
Nodular thyroid diseases are common in mountainous areas of the eastern region of the country, ${ }^{10}$ and thyroid cancer is the second-most common cancer among females $(10.2 \%) .{ }^{11}$ In the United States, seven percent of the population has a palpable thyroid nodule, ${ }^{12}$ but only one of 20 clinically identified nodules is malignant. ${ }^{13}$ An estimated 30million individuals in the United States have thyroid nodules larger than one $\mathrm{cm}$. With the high prevalence of thyroid nodules, 30,000 patients are diagnosed yearly with thyroid malignancy. ${ }^{13,14}$

Given the high prevalence of nodules, FNA is an important screening test8. Every patient with a palpable or incidental nodule is a candidate for FNA. A thyroid nodule that is either iso- or hypofunctioning, according to a radionuclide scan, should be considered for FNA. ${ }^{13-15}$ Incidental lesions detected by ultrasound have a $10-15 \%$ cancer risk and should undergo sonographic evaluation. ${ }^{16} \mathrm{~A}$ thyroid nodule of any size and shape that is determined sonographically should also be evaluated by FNA. ${ }^{17,18}$

Currently, confusion surrounds the reporting of FNA for thyroid nodules, because of differently named lesion categories, unclassified descriptive reports, and varying surgical and pathological terminology. ${ }^{16}$ This confusion has led to wide variance in the sensitivity 
and specificity of what can be considered true or false positive or negative results, which has led to uncertainty among clinicians on how to manage patients with thyroid nodules that do not have a clear, informative result in thyroid FNA. ${ }^{18}$

In 2007, the National Cancer Institute (NCI) held the NCI Thyroid Fine Needle Aspiration State of the Science Conference, wherein the terminology and morphologic criteria for reporting thyroid FNA were decided, forming a framework for The Bethesda System for Reporting Thyroid Cytopathology (TBSRTC). This solved much of the confusion. ${ }^{16,17}$

The Bethesda system improves communication among cytopathologists and surgeons. This allows reliable sharing of data and comparison between laboratories, nationally and internationally, by establishing a common language and reliable conclusions. ${ }^{17-19}$

Few studies have validated the utility and diagnostic accuracy of FNA of thyroid nodules across Saudi Arabia, reported the risk of thyroid malignancies among the Saudi population, or provided feedback on TBSRTC after it was implemented in Saudi Arabia. In contrast, several international studies and reviews have been published on these topics in other countries. ${ }^{20-27}$

The purpose of this study is to categorize thyroid lesions by FNA using the Bethesda FNA classification system, including the following categories:

a. Non-diagnostic, benign, atypical follicular lesions of undetermined significance

b. Follicular/Hurthle cell neoplasm

c. Suspicious for malignancy

d. Malignant sub-categories

The purpose is also to determine the rate of malignancy in each cytological category by correlating the results with histopathologic diagnoses on the resected specimens.

\section{Materials and methods}

A retrospective cross-sectional study was conducted on the charts in which all cases of thyroid nodules, presented to the OPC between from September 2009 to August 2015 at King Abdul-Aziz National Guard Hospital. All cases of thyroid nodules that underwent preoperative cytological examination by FNA and concurrent postoperative histopathologic examination were included. The FNA diagnoses were reclassified using TBSRTC, including:

\section{i. Non-diagnostic}

ii. Benign

iii. Atypical follicular lesion of undetermined significance

iv. Follicular /hurthle cell neoplasm

v. Suspicious for malignancy

vi. Malignant categories

vii. The rate of malignancy based on final histopathological evaluation was analyzed for each of these cytological groups.

\section{Results and discussion}

Our demographic of our study sample set, divided in to age, gender, family history, main presenting symptoms, Bethesda grading, pathology and type of pathology as shown in Table 1, The mean age of our study group was 44.59years, with a range from 14-96years among 237 patients and majority of cases clustered in fourth decade. Of these patients, $40(16.9 \%)$ were males and $197(83.1 \%)$ were females, we found there were more percentage females in the study compare to male's gender and the malignancy rate higher in the 4, 5, 6 grading in each gender as shown in Table 2, we found only (5.1\%) had family history of thyroid disease, thyroid symptoms were examined by the visual examination of neck. It was observed that $(45.1 \%)$ patients had neck swelling with compression symptoms while (54.9\%) had neck swelling without compression symptoms as shown in Table 1.

The Age distribution of thyroid lesion based on FNAC according to Bethesda System and correlation with pathology type, the majority of our patient were between age (35-45)years 75 patient and age (45-55)years 55 patient, the Bethesda grading is very significantly related with the pathology results given that it is highly sensitive on determining pathology according to that age as shown in Table 3.

Table I Characteristics of Study Sample Set

\begin{tabular}{|c|c|c|c|c|c|}
\hline \multicolumn{2}{|c|}{ Demographics $(\mathrm{N}=\mathbf{2 3 7})$} & \multirow{2}{*}{$\begin{array}{l}\text { Min } \\
14\end{array}$} & \multirow{2}{*}{$\begin{array}{l}\text { Max } \\
96\end{array}$} & \multirow{3}{*}{$\begin{array}{l}\text { Mean } \\
44.59\end{array}$} & \multirow{2}{*}{$\begin{array}{l}\text { SD } \\
13.3\end{array}$} \\
\hline Age & & & & & \\
\hline & & $\mathrm{N}$ & $\%$ & & \\
\hline \multirow[t]{2}{*}{ Gender } & Male & 40 & 16.9 & & \\
\hline & Female & 197 & 83.1 & & \\
\hline \multirow[t]{2}{*}{ Family History } & Positive & 12 & 5.1 & & \\
\hline & Negative & 225 & 94.9 & & \\
\hline \multirow{2}{*}{$\begin{array}{l}\text { Main Presenting } \\
\text { Symptom }\end{array}$} & Neck swelling with compression & 107 & 45.1 & & \\
\hline & Neck swelling without compression & 130 & 54.9 & & \\
\hline \multirow[t]{6}{*}{ Bethesda Grading } & Non-diagnostic or unsatisfactory & 10 & 4.2 & & \\
\hline & Benign & 93 & 39.2 & & \\
\hline & Atypia of undetermined significance or follicular lesion & 37 & 15.6 & & \\
\hline & Follicular neoplasm or suspicion of a follicular neoplasm & 21 & 8.9 & & \\
\hline & Suspicion of malignancy & 40 & 16.9 & & \\
\hline & Malignant & 36 & 15.2 & & \\
\hline \multirow[t]{2}{*}{ Pathology } & Benign & 135 & 57 & & \\
\hline & Malignant & 102 & 43 & & \\
\hline Type of Pathology & A benign follicular nodule (includes adenomatous nodule, colloid nodule) & 119 & 50.2 & & \\
\hline
\end{tabular}


Table Continued...

\begin{tabular}{|c|c|c|c|c|}
\hline Demographics $(\mathbf{N}=237)$ & Min & Max & Mean & SD \\
\hline Lymphocytic (Hashimoto) thyroiditis & 5 & 2.1 & & \\
\hline Granulomatous (subacute) thyroiditis & 6 & 2.5 & & \\
\hline Hurthle cell (oncocytic) & 17 & 7.2 & & \\
\hline Papillary thyroid carcinoma & 84 & 35.4 & & \\
\hline Poorly differentiated carcinoma & I & 0.4 & & \\
\hline Medullary thyroid carcinoma & 3 & 1.3 & & \\
\hline Metastatic carcinoma & 2 & 0.8 & & \\
\hline
\end{tabular}

Table 2 The Age distribution of thyroid lesion based on FNAC according to Bethesda System and correlation with pathology type

\begin{tabular}{|c|c|c|c|c|c|}
\hline \multirow[t]{2}{*}{ Bethesda grading } & & \multirow[t]{2}{*}{ Total } & \multicolumn{2}{|c|}{ Pathology N (\%) } & \multirow[t]{2}{*}{ p value } \\
\hline & & & Benign & Malignant & \\
\hline \multirow[t]{6}{*}{ Age less than 35 years } & Non-diagnostic or unsatisfactory & 3 & $3(100.0 \%)$ & $0(0.0 \%)$ & $<0.00 \mathrm{le}$ \\
\hline & Benign & 26 & $26(100.0 \%)$ & $0(0.0 \%)$ & \\
\hline & Atypia of undetermined significance or follicular lesion & 5 & $4(80.0 \%)$ & I (20.0\%) & \\
\hline & Follicular neoplasm or suspicious for a follicular neoplasm & 6 & $0(0.0 \%)$ & $6(100.0 \%)$ & \\
\hline & Suspicious of malignancy & 8 & $2(25.0 \%)$ & $6(75.0 \%)$ & \\
\hline & Malignant & II & $0(0.0 \%)$ & II (I00.0\%) & \\
\hline \multirow[t]{6}{*}{$35-45$ years } & Non-diagnostic or unsatisfactory & 2 & $2(100.0 \%)$ & $0(0.0 \%)$ & $<0.001 \mathrm{e}$ \\
\hline & Benign & 23 & $23(100.0 \%)$ & $0(0.0 \%)$ & \\
\hline & Atypia of undetermined significance or follicular lesion & 15 & II (73.3\%) & $4(26.7 \%)$ & \\
\hline & Follicular neoplasm or suspicious for a follicular neoplasm & 5 & $0(0.0 \%)$ & $5(100.0 \%)$ & \\
\hline & Suspicious of malignancy & 15 & $0(0.0 \%)$ & $15(100.0 \%)$ & \\
\hline & Malignant & 15 & I (6.7\%) & $14(93.3 \%)$ & \\
\hline \multirow[t]{6}{*}{$45-55$ years } & Non-diagnostic or unsatisfactory & 3 & $3(100.0 \%)$ & $0(0.0 \%)$ & $<0.00 \mathrm{le}$ \\
\hline & Benign & 22 & $20(90.9 \%)$ & $2(9.1 \%)$ & \\
\hline & Atypia of undetermined significance or follicular lesion & II & $9(81.8 \%)$ & $2(18.2 \%)$ & \\
\hline & Follicular neoplasm or suspicious for a follicular neoplasm & 6 & I (I6.7\%) & $5(83.3 \%)$ & \\
\hline & Suspicious of malignancy & 7 & $0(0.0 \%)$ & 7 (100.0\%) & \\
\hline & Malignant & 6 & I (I6.7\%) & $5(83.3 \%)$ & \\
\hline \multirow[t]{6}{*}{56 years and older } & Non-diagnostic or unsatisfactory & 2 & $2(100.0 \%)$ & $0(0.0 \%)$ & $<0.001 \mathrm{e}$ \\
\hline & Benign & 22 & $20(90.9 \%)$ & $2(9.1 \%)$ & \\
\hline & Atypia of undetermined significance or follicular lesion & 6 & $6(100.0 \%)$ & $0(0.0 \%)$ & \\
\hline & Follicular neoplasm or suspicious for a follicular neoplasm & 4 & I (25.0\%) & $3(75.0 \%)$ & \\
\hline & Suspicious of malignancy & 10 & $0(0.0 \%)$ & $10(100.0 \%)$ & \\
\hline & Malignant & 4 & $0(0.0 \%)$ & $4(100.0 \%)$ & \\
\hline e-significant using chi-s & are test at less than 0.05 & & & & \\
\hline
\end{tabular}

Table 3 Bethesda Grading by gender

\begin{tabular}{|c|c|c|c|c|c|}
\hline \multirow[t]{2}{*}{ Variables } & & \multirow[t]{2}{*}{ Total } & \multicolumn{2}{|l|}{ Pathology } & \multirow[t]{2}{*}{ p-value } \\
\hline & & & Benign & Malignant & \\
\hline \multirow[t]{6}{*}{ Bethesda Grading } & Non-diagnostic or unsatisfactory n (\%) & 2 & $2(100.0 \%)$ & $0(0.0 \%)$ & $<0.00 \mathrm{lc}$ \\
\hline & Benign $n(\%)$ & 21 & $20(95.2 \%)$ & $\mathrm{I}(4.8 \%)$ & \\
\hline & Atypia of undetermined significance or follicular lesion n (\%) & 4 & $4(100.0 \%)$ & $0(0.0 \%)$ & \\
\hline & Follicular neoplasm or suspicious for a follicular neoplasm n (\%) & 5 & $\mathrm{I}(20.0 \%)$ & $4(80.0 \%)$ & \\
\hline & Suspicious of malignancy n (\%) & 5 & $\mathrm{I}(20.0 \%)$ & $4(80.0 \%)$ & \\
\hline & Malignant n (\%) & 3 & $0(0.0 \%)$ & $3(100.0 \%)$ & \\
\hline \multirow{6}{*}{$\begin{array}{l}\text { Bethesda } \\
\text { Gradingb }\end{array}$} & Non-diagnostic or unsatisfactory n (\%) & 8 & $8(100.0 \%)$ & $0(0.0 \%)$ & $<0.00 \mathrm{lc}$ \\
\hline & Benign n (\%) & 72 & $69(95.8 \%)$ & $3(4.2 \%)$ & \\
\hline & Atypia of undetermined significance or follicular lesion $n(\%)$ & 33 & $26(78.8 \%)$ & $7(21.2 \%)$ & \\
\hline & Follicular neoplasm or suspicious for a follicular neoplasm n (\%) & 16 & $\mathrm{I}(6.3 \%)$ & $15(93.8 \%)$ & \\
\hline & Suspicious of malignancy $n(\%)$ & 35 & $\mathrm{I}(2.9 \%)$ & $34(97.1 \%)$ & \\
\hline & Malignant n (\%) & 33 & $2(6.1 \%)$ & $31(93.9 \%)$ & \\
\hline
\end{tabular}

Gender: a-Male

b-Female

c-significant using Chi-Square test @ $<0.05$ level. 
We reviewed 237 thyroid FNA samples and recorded interpretations according to the proposed standardized 6 categories and pursued follow-up cytology and histology. Out of the 237 FNAs $4.2 \%$ were non diagnostic, $39.2 \%$ were benign, $15.6 \%$ were atypia of undetermined significance or follicular lesion, $8.9 \%$ were follicular neoplasm or suspicious for a follicular neoplasm, $16.9 \%$ were suspicious of malignancy, and $15.2 \%$ were malignant as shown in Table 1, the rates of malignancy in histopathology were as follows: non diagnostic, $0.0 \%$ benign, $4.3 \%$; Atypia of undetermined significance or follicular lesion 18.9\%; Follicular neoplasm or suspicious for a follicular neoplasm 34\%: Suspicious of malignancy $95.0 \%$ and malignant $94.4 \%$ as shown in Table 4.

The type of pathology has a significant relationship with Bethesda grading, especially results is mainly coming from a benign follicular nodule, hurthle cell and papillary thyroid carcinoma. When patient was categorized under a benign follicular nodule (119) patient, $68 \%$ were under category 2 (benign) and 27\% were under category 3 (atypia of undetermined significance or follicular lesion).

When patient was categorized under hurthle cell (17) patient, 100 $\%$ were under category 4 (Follicular neoplasm), When patient was categorized under the papillary thyroid carcinoma (84) patient, 3, $6 \%$, were fall under category 2 (benign), category 5 (Suspicious of malignancy), 6 (malignant) and 3 (atypia of undetermined significance or follicular lesion) which had 37, 34 and 7 patients respectively and covered around $36 \%$ of total patients as shown in Table 5 .

Table 4 Correlation between Bethesda grading and pathology type

\begin{tabular}{|c|c|c|c|c|c|}
\hline \multirow[t]{2}{*}{ Variables } & & \multirow[t]{2}{*}{ Total } & \multicolumn{2}{|c|}{ Pathology N (\%) } & \multirow[t]{2}{*}{ p value } \\
\hline & & & Benign & Malignant & \\
\hline Total & & 237 & $\begin{array}{l}135 \\
(57.0 \%)\end{array}$ & $\begin{array}{l}102 \\
(43.0 \%)\end{array}$ & N/A \\
\hline \multirow[t]{6}{*}{ Bethesda Grading } & Non-diagnostic or unsatisfactory & 10 & $\begin{array}{l}10 \\
(100.0 \%)\end{array}$ & $0(0.0 \%)$ & $<0.00 \mathrm{la}$ \\
\hline & Benign & 93 & $89(95.7 \%)$ & $4(4.3 \%)$ & \\
\hline & Atypia of undetermined significance or follicular lesion & 37 & $30(81.1 \%)$ & $7(18.9 \%)$ & \\
\hline & Follicular neoplasm or suspicious for a follicular neoplasm & 21 & $14(66 \%)$ & $7(34 \%)$ & \\
\hline & Suspicious of malignancy & 40 & $2(5.0 \%)$ & $38(95.0 \%)$ & \\
\hline & Malignant & 36 & $2(5.6 \%)$ & $34(94.4 \%)$ & \\
\hline
\end{tabular}

Table 5 The correlation between the type of pathology with Bethesda grading

\begin{tabular}{|c|c|c|c|c|c|c|c|c|}
\hline & & $\begin{array}{l}\text { Non- } \\
\text { Diagnostic or } \\
\text { Unsatisfactory }\end{array}$ & Benign & $\begin{array}{l}\text { Atypia of } \\
\text { undetermined } \\
\text { Significance } \\
\text { or follicular } \\
\text { Lesion }\end{array}$ & Pathology & Total & $\begin{array}{l}\text { Bethesda } \\
\text { Grading N (\%) }\end{array}$ & pvalue \\
\hline \multirow[t]{2}{*}{ Total } & 237 & $10(4.2 \%)$ & $93(39.2 \%)$ & $37(15.6 \%)$ & $2 I(8.9 \%)$ & $40(16.9 \%)$ & $36(15.2 \%)$ & N/A \\
\hline & 119 & $10(8.4 \%)$ & $81(68.1 \%)$ & $27(22.7 \%)$ & $\mathrm{I}(0.8 \%)$ & $0(0.0 \%)$ & $0(0.0 \%)$ & $<0.00 \mathrm{la}$ \\
\hline \multicolumn{9}{|c|}{ A benign follicular nodule (includes adenomatous nodule, colloid nodule } \\
\hline $\begin{array}{l}\text { Lymphocytic (Hashimoto) } \\
\text { thyroiditis }\end{array}$ & 5 & $0(0.0 \%)$ & $2(40.0 \%)$ & $3(60.0 \%)$ & $0(0.0 \%)$ & $0(0.0 \%)$ & $0(0.0 \%)$ & \\
\hline $\begin{array}{l}\text { Granulomatous (Subacute) } \\
\text { Thyroiditis }\end{array}$ & 6 & $0(0.0 \%)$ & $6(100.0 \%)$ & $0(0.0 \%)$ & $0(0.0 \%)$ & $0(0.0 \%)$ & $0(0.0 \%)$ & \\
\hline Hurthle cell (Oncocytic) & 17 & $0(0.0 \%)$ & $0(0.0 \%)$ & $0(0.0 \%)$ & $17(100.0 \%)$ & $0(0.0 \%)$ & $0(0.0 \%)$ & \\
\hline Papillary thyroid Carcinoma & 84 & $0(0.0 \%)$ & $3(3.6 \%)$ & $7(8.3 \%)$ & $3(3.6 \%)$ & 37 (44.0\%) & $34(40.5 \%)$ & \\
\hline $\begin{array}{l}\text { Poorly differentiated } \\
\text { Carcinoma }\end{array}$ & 1 & $0(0.0 \%)$ & $0(0.0 \%)$ & $0(0.0 \%)$ & $0(0.0 \%)$ & $0(0.0 \%)$ & I (I00.0\%) & \\
\hline $\begin{array}{l}\text { Medullary Thyroid } \\
\text { Carcinoma }\end{array}$ & 3 & $0(0.0 \%)$ & $0(0.0 \%)$ & $0(0.0 \%)$ & $0(0.0 \%)$ & $3(100.0 \%)$ & $0(0.0 \%)$ & \\
\hline Metastatic Carcinoma & 2 & $0(0.0 \%)$ & I (50.0\%) & $0(0.0 \%)$ & $0(0.0 \%)$ & $0(0.0 \%)$ & I (50.0\%) & \\
\hline
\end{tabular}

a-significant using chi-square test at less than 0.05

\section{Conclusion}

Our study concluded that FNAC reporting using TBSRTC highly correlated with histopathological diagnosis. The Bethesda system is a standardized system of reporting thyroid cytopathology, improving communication between cytopathologists and clinicians leading to ideal management approach. The Bethesda system for reporting thyroid cytopathology can estimate the risk of malignancy and have important prognostic information regarding the cancer type, variant, and risk of recurrence.

\section{Acknowledgments}

None.

\section{Conflicts of interest}

Author declares there are no conflicts of interest.

\section{Funding}

None. 


\section{References}

1. Mazzaferri EL. Management of a solitary thyroid nodule. New England Journal of Medicine. 1993;328:553-559.

2. Gharib H, Papini E, Valcavi R, et al. American Association of Clinical Endocrinologists and Associazione Medici Endocrinologi medical guidelines for clinical practice for the diagnosis and management of thyroid nodules. Endocrinology Practice. 2006;12(1): 63-102.

3. Cooper DS, Doherty GM, Haugen BR, et al. Revised American Thyroid Association management guidelines for patients with thyroid nodules and differentiated thyroid cancer. Thyroid . 2009;19(11):1167-1214.

4. Ries LAG, Melbert D, Krapcho M. SEER Cancer Statistics Review, 1975-2005. Bethesda, MD: National Cancer Institute. 2007.

5. Chen AY, Jemal A, Ward EM. Increasing incidence of differentiated thyroid cancer in the United States, 1988-2005. Cancer. 2009;115(16):3801-3807.

6. Hassell LA, Gillies EM, Dunn ST. Cytologic and molecular diagnosis of thyroid cancers: Is it time for routine reflex testing? Cancer Cytopathol. 2011;120:7-17.

7. Sakorafas GH. Thyroid nodules; interpretation and importance of fineneedle aspiration (FNA) for the clinician - practical considerations. Surg Oncol. 2010;19(4):e1300-e139.

8. Yoder BJ, Redman R, Massoll NA. Validation of a five-tier cytodiagnostic system for thyroid fine needle aspiration biopsies using cytohistologic correlation. Thyroid. 2006;16(8):781-786.

9. Cibas ES, Ali SZ. The Bethesda System for Reporting Thyroid Cytopathology. American Journal of Clinical Pathology. 2009;132(5):658-665

10. Abdullah L, Thomas J, Fadaq R. Fine needle aspiration in the management of thyroid nodules: Experience at King Khalid National Guard Hospital, Jeddah. Ann Saudi Med. 2003

11. ;23(6):408-409.

12. Haya SA. Cancer incidence report in Saudi Arabia. National Cancer Registry. Ministry of Health, Kingdom of Saudi Arabia. 2006.

13. Hegedüs L. The thyroid nodule. New England Journal of Medicine. 2004;351(17):1764-1771.

14. Wong CK, Wheeler MH. Thyroid nodules: Rational management. World J Surg. 2000;24(8):934-941.

15. Haugen BR, Alexander EK, Bible KC, et al. American Thyroid Association Guidelines Taskforce: Management guidelines for patients with thyroid nodules and differentiated thyroid cancer. Thyroid. 2006;16(2):109-142.

16. Liebeskind A, Sikora AG, Komisar A, et al. Rates of malignancy in incidentally discovered thyroid nodules evaluated with sonography and fine-needle aspiration. J Ultrasound Med. 2005;24(5):629-634.
17. Layfield LJ, Cibas ES, Baloch Z. Thyroid fine needle aspiration cytology: A review of the National Cancer Institute state of the science symposium. Cytopathology. 2010;21(2):75-85.

18. Cibas ES, Alexander EK, Benson CB, et al. Indications for thyroid FNA and pre-FNA requirements: a synopsis of the National Cancer Institute Thyroid Fine-Needle Aspiration State of the Science Conference. Diagn Cytopathol. 2008;36(6):390-399.

19. Nayar R, Ivanovic M. The indeterminate thyroid fine-needle aspiration: Experience from an academic center using terminology similar to that proposed in the 2007 National Cancer Institute Thyroid Fine Needle Aspiration State of the Science Conference. Cancer. 2009;117(3):195-202.

20. Cibas ES, Ali SZ (2009) The Bethesda System for Reporting Thyroid Cytopathology. Thyroid 19(11): 1159-1165.

21. Baloch ZW, Alexander EK, Gharib H, et al. Overview of Diagnostic Terminology and Reporting. In: Ali SZ \& Cibas ES (Eds.), The Bethesda System for Reporting Thyroid Cytopathology. Springer, New York, USA. 2010. p. 1-4.

22. Jo VY, Stelow EB, Dustin SM, et al. Malignancy risk for fineneedle aspiration of thyroid lesions according to the Bethesda System for Reporting Thyroid Cytopathology. Am J Clin Pathol . 2010;134(3):450-456

23. Al-Shraim MM, Hussein MR, Musalam AO, et al. Hurthle cell neoplasms of thyroid in South-Western region of Saudi Arabia. West Afr J Med. 2010;29(6):398-402.

24. Althoubaity F. Preoperative fine needle aspiration cytology versus frozen section in thyroid surgery. Egyptian Journal of Surgery. 2006;25(1):20-28.

25. El Hag IA, Kollur SM, Chiedozi LC. The role of FNA in the initial management of thyroid lesions: 7-year experience in a district general hospital. Cytopathology. 2003;14(3):126-130.

26. Al-Rikabi AC, Al-Omran M, Cheema M, et al. Pattern of thyroid lesions and role of fine needle aspiration cytology (FNA) in the management of thyroid enlargement: A retrospective study from a teaching hospital in Riyadh. APMIS. 1998;106(11):1069-1074.

27. Wu HH, Rose C, Elsheikh TM. The Bethesda system for reporting thyroid cytopathology: An experience of 1,382 cases in a community practice setting with the implication for risk of neoplasm and risk of malignancy. Diagn Cytopathol. 2011;40(5):399-403.

28. Jung CK, Lee KY, Bae JS, et al. Application of Bethesda System for Reporting Thyroid Aspiration Cytology. The Korean Journal of Pathology. 2010;44(5):521-527. 